\title{
Currency Crisis Transmission Through Trade Channel: Asian and Mexican Crises Revisited
}

\author{
Saleheen Khan* \\ Department of Economics, Minnesota State University, USA
}

\begin{abstract}
This paper provides support to the existing empirical evidence that trade linkages play an important role in explaining the magnitude of currency crises, in addition to macroeconomic fundamentals and stock market dynamics. We apply pooled regression analysis in an attempt to better understand the effect of trade on the Asian Crises period of 1997 1998 and the Mexican Peso Crisis of 1994 1995. Our empirical results show that trade variables explain the aforementioned crises and their contagion. We also find that the magnitude of the trade channel was similar in both cases.
\end{abstract}

JEL Classifications: F31, F30, F10

Keywords: Currency crises, Contagion, Trade

* Corresponding Author: Saleheen Khan; Professor, Department of Economics, Minnesota State University, Mankato, 133 Morris Hall, Mankato, MN 56002. E-mail:saleheen.khan@mnsu.edu 


\section{Introduction}

The decade of the nineties experienced several major currency crises, viz., the European Monetary System (EMS) crisis, 1992 1993; the Tequila crisis, 1994 1995; the Asian crisis of 1997 1998. These crises were followed by the more recent Brazilian and Russian currency crises. Such crises trigger major shocks to an economy. A key concern is that, when a crisis occurs it does not stay confined within borders of the country. Hence, it is of little surprise that the propagation of such crises across countries has been a matter of intense research, generating a sizeable literature over the past two decades.

Contagion through trade link has a strong theoretical and empirical foundation. On the theoretical front Haidar (2012), Gerlach and Smets (1995), Corsetti, Pesenti, Roubini, and Tille (2000), and Huh and Kasa (2001) have made substantial contributions. Garlach and Smets (1995) is the first paper to theoretically model a crisis to show how a speculative attack and subsequent devaluation in one currency can affect trade flows and devaluation in another currency. A successful attack on one exchange rate causes its real depreciation and improves the competitiveness of the country's merchandise exports. This produces trade deficits in the second country, a gradual decline in the international reserves of its central bank and ultimately a speculative attack on its currency. A secondary effect of initial devaluation is also model in their paper. The initial devaluation in the first country lowers the import price in the second country, which reduces its aggregate price level and aggregate demand. Subsequent foreign exchange swap in the second country further depletes its international reserves and make its exchange rate parity subject to collapse. Corsetti, Pesenti, Roubini, and Tille (2000) used a micro based theoretical model to show how trade can transmit a currency crisis. The devaluation in one country lowers the relative price of its exports, which shifts the demand away from countries that produce similar goods. On the other hand, the cheaper exports could improve the terms of trade for other countries. The country that devalues its currency does not necessarily improve its welfare in this model. In fact, the devaluing country could beggar thy-self if other countries improvement in terms of trade dominates the increase in exports of the country that devaluates. Huh and Kasa (2001) modeled the pressure for competitive devaluation that arises when a group of countries export to a common foreign market. Haidar (2012) introduces 
a three-country dynamic general equilibrium model to show how currency crisis transmit through real (trade) sector channel. It shows how changes in a foreign country's capital flow can influence home country's exchange rates though terms of trade.

Notable empirical studies pertaining to the linkage between trade and currency crises, include Eichengreen et al. (1996) and Glick and Rose (1999), Forbes (2004), Kaminsky and Reinhart (2000), Khan et al. (2005), and Haile and Pozo (2008). These studies found that the strength of trade links was helpful in explaining the contagious nature of currency crises. ${ }^{1}$

Eichengreen et al. (1996) used thirty years of panel data from twenty industrial countries to find evidence of contagion. They found currency crisis tends to spread more easily to countries closely linked by trade than to countries with similar macroeconomic fundamentals. Glick and Rose (1999) show that trade patterns are important in explaining how crisis spread above and beyond macro-economic similarities using five different currency crises episodes (1971, 1973, 1992, 1994, and 1997). Currency crises tend to affect cluster of countries linked together by international trade flows. Trade linkages are measured through countries exports to the common third market or through their bilateral trade. Forbes (2004) uses firms-level data set for 10,000 companies in 46 countries to examine Asian and Russian currency crises. The paper showed that trade channels are important factor to explain spread of crises internationally. Kaminsky and Reinhart (2000) the role of international bank lending, cross market hedging, and bilateral and thirdparty trade in propagation for currency crises. They used a sample of monthly data for 1970 1998 and analyzed 80 currency crises for number of industrial and developing countries and found that trade links can explain the observed historical pattern of contagion. Khan et al. (2005) analyzed the historical trade pattern in seven South East Asian countries to show trade links were important in explaining the propagation of Asian currency crisis. Haile and Pozo (2008) show that countries face currency crisis due to unsustainable macroeconomic fundamentals and contagion through trade channel. They use quarterly data from 1960 1998 for a set of 37 advanced and emerging markets economies to find that contagion is regional and it operates through

${ }^{1}$ In this study we consider only fundamental-based contagion and is defined as the spread of crises from the first victim to the other countries through macroeconomic, financial or trade channels. 
trade channel.

A good understanding of the relationship between stock price and exchange rate may prove helpful in predicting the advent of an impending crisis. Ito and Hashimoto (2005) noted that decline in stock prices often serves as a leading indicator of crises. The slowdown in the economy negatively affects stock prices when investors pull their capital out of the country, putting additional downward pressure on the economy. In case of Thailand, the stock price was at its peak in the mid-1990s; and had fallen by fifty percent on the eve of the crisis. The significant decline in the stock prices for three years pushed an already weakened economy into another recession, setting the stage for the crisis. Granger et al. (2000) also found strong linkages between the stock price and currency markets during the Asian currency crisis. Using a Vector Autoregressive (VAR) model, Khalid and Kawai (2003), on the other hand, conclude that there was no spillover effect between stock markets and foreign exchange markets during the 1997 Asian crisis. Their finding is based on an analysis of crises involving nine Asian countries.

The foregoing discussion points to a possible impact of stock market dynamics on currency markets. Therefore, to extract the true effect of trade channel in explaining the magnitude of a currency crisis, it is imperative that we control for both the macroeconomic fundamentals and the stock market volatility. In a seminal work, Ito and Hashimoto (2005) empirically demonstrated the possibility that stock market can act as a leading indicator for an impending currency crisis. In an earlier paper, the authors find evidence of statistically significant high-frequency contagion among Asian countries in both exchange rate and the stock prices and high-frequency spillover effect tied to the international trade channel. While their analysis made significant contribution, further evidence likely would help policy makers to better understand the dynamics of trade vis-a-vis currency crisis and thus permit them to intervene, as needed, to prevent a crisis or mitigate the effects from a shock arising out of such crises.

The objective of this paper is to present further empirical evidence in favor of the claim that trade linkages can be important in explaining the severity of a currency crisis, above and beyond the effects of macroeconomic fundamentals and financial market dynamics. The paper uses a sample of 25 emerging nations from the Mexican peso crisis of 1994 1995 and the Asian crisis of 1997 1998. We used two of the major currency crises episodes in the 
last two decades in our sample. The pooled regression approach used in the paper is capable of explaining the Tequila crisis as well as the cross-country variation in the severity of the Asian crisis. Such knowledge will help policy makers to detect warning signs of early trouble and take adequate precautions.

Our research questions may look similar and we reach the same conclusion as Glick and Rose (1999). Despite some similarity, there are important differences between the two. First, we look for structural change in the models hoping that it might help to explain the spread of the crises by applying a pooled regression method. Second, our method permits us to address the presence of country effects. Third, in addition to the macroeconomic fundamentals, a la, Glick and Rose (1999), we also control for the stock market dynamics. Since trade flows are highly correlated with variation in equity markets in general, we try to avoid the omitted variable bias by incorporating it in our model. Many of the previous studies suffer from this bias. It is of interesting to note that even after using a significantly different approach, the conclusion remains the same. Our findings thus can be seen as complementing their results. The paper thus contributes to the literature by enhancing the degree of robustness to the argument that trade is an important channel to explain the propagation of a currency crisis.

The rest of the paper is organized as follows. Section 2 outlines our methodology. Empirical results are reported in Section 3. Section 4 concludes the paper with a note on directions for future research.

\section{Methodology}

In this paper we provide empirical evidence to argue that trade channels are important in explaining the contagion for the Asian and the Mexican crises, not how and when the crisis originated in the first victim. As a matter of fact, we want to know how a crisis spreads across emerging markets from the first victim. As in Glick and Rose (1999), our dependent variable is continuous, but we apply Ordinary Least Squares (OLS) within a pooled regression framework. This crisis index provides our dependent variable in helping to explain the exchange market pressure during the currency crises. The benchmark regression framework takes the following form: 


$$
\text { Crisis }_{j}=\alpha_{0}+\sum \beta_{i} \text { Trade }_{i j}+\sum \delta_{i} \text { Macro }- \text { controls }_{i j}+\varepsilon_{j}
$$

where, Crisis $_{j}$ is a continuous measure of exchange market pressure calculated as the weighted average of the percentage depreciation of nominal exchange rate with respect to US dollar and the percentage decline in foreign reserves for six months following the start of the crisis. ${ }^{2}$ The weights are determined so as to equalize the volatility of the components. We calculate the inverse of the variances for each variable with three years of monthly data prior to each crisis. Then we compute weights of each variable as its inverse of the variance over the sum of the inverses of the variances. ${ }^{3,4}$ Crisis indices for Asian and Mexican currency crises are graphed in Figure 1 and 2 respectively.

\section{Figure 1. Crisis index (Asian currency crisis)}

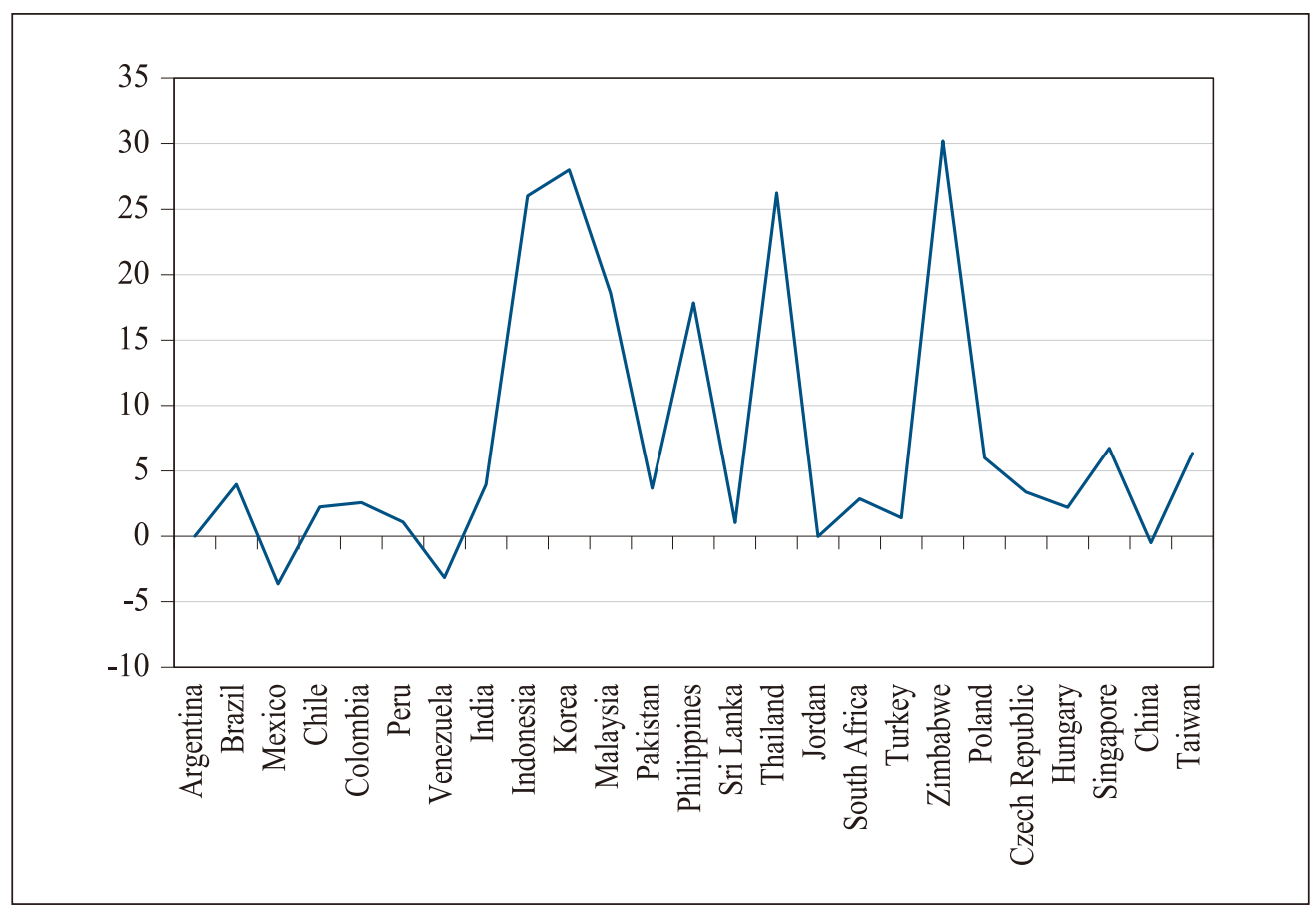

\footnotetext{
${ }^{2}$ For the Mexican peso crisis, change is measured from end of November 1994, while for the Asian crisis it is measured from end of June 1997.

${ }^{3}$ Sachs, Tornell and Velasco (1996), Tornell (1999), and Eichengreen, Rose and Wyplosz (1996) calculated their crisis index in a similar fashion.

${ }^{4}$ Using interest rate as a policy tool to fend off speculative attack s possible, but such data could not be incorporated in our crisis index due to lack of data in emerging market.
} 


\section{Figure 2. Crisis index (Mexican crisis)}

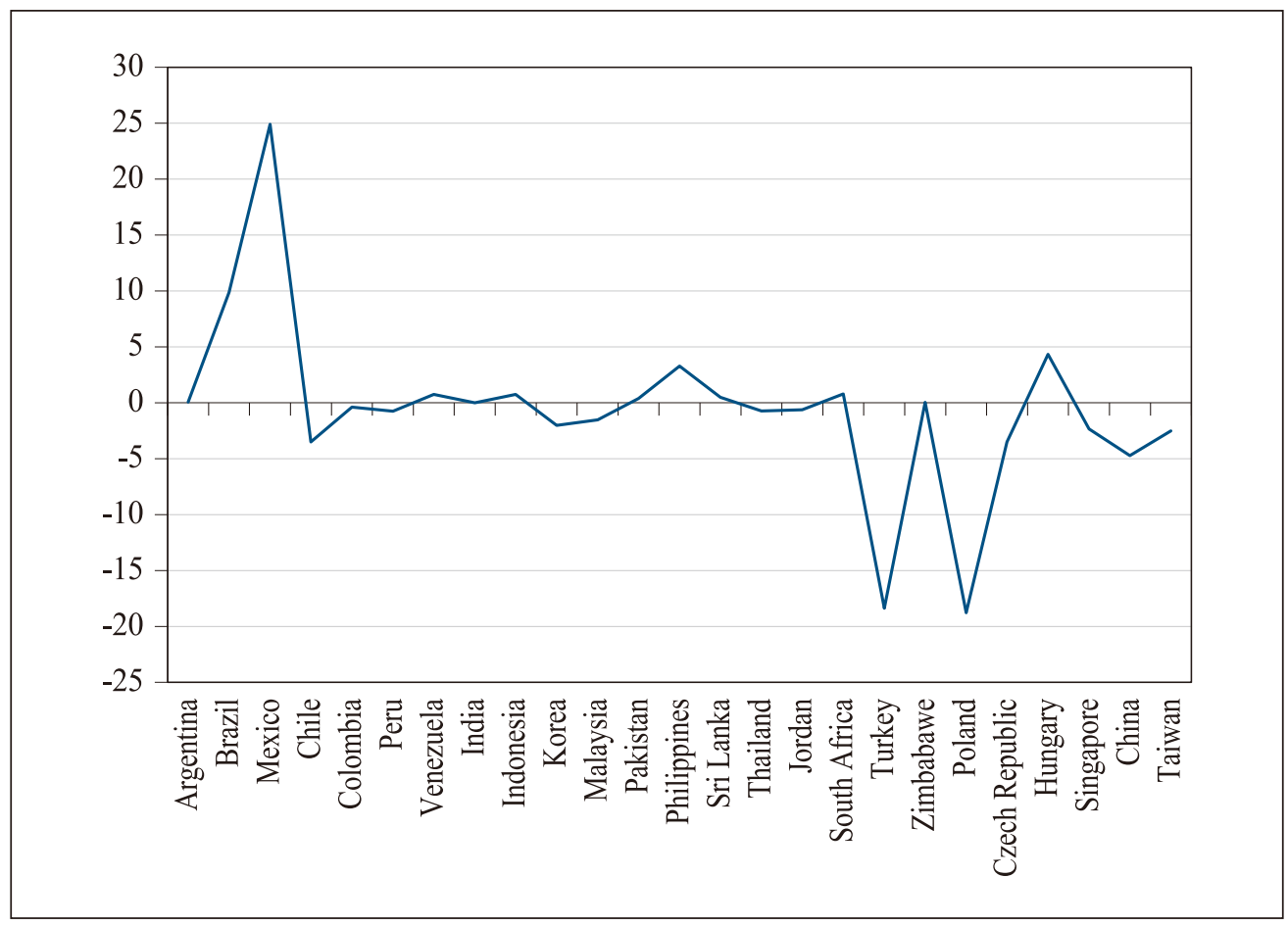

\section{Trade Indices}

We calculate $T M E C_{j}$ (Third market Export Competition) index as follows:

$$
T M E C_{j}(\text { share }) \equiv \sum_{r}\left[\left(\frac{x_{0 r}+x_{j r}}{x_{0}+x_{j}}\right)\left(1-\frac{\left|\frac{x_{j r}}{x_{j}}-\frac{x_{0 r}}{x_{0}}\right|}{\frac{x_{j r}}{x_{j}}+\frac{x_{0 r}}{x_{0}}}\right)\right]
$$

where, 0 refers to ground zero (first victim) country and $r$ stands for a common third market where ground zero and country $j$ compete in exports, $X_{j r}$ represents country $j$ 's export to a third market $r . X_{j}$ denotes export from country $j$ to world export market. The first component of the equation is a measure of the overall importance of a third market to country $j$ and 0 . The second component captures the extent to which country $j$ and the first victim compete with respect to trade share in a third market. We divide the World export market into five mutually exclusive regions: Africa and Middle East, 
Latin America, the U.S. and Canada, Europe, and Asia and Oceania, and calculate export competition of country $j$ with the first victim in each one of the five markets. The country index is computed by summing up the TMEC for all five markets.

We also calculate a variant measure of third market trade competition that uses absolute value of exports to a third market rather than export share.

$$
\operatorname{TMEC}_{j}(\text { absolute }) \equiv \sum_{r}\left[\left(\frac{x_{0 r}+x_{j r}}{x_{0}+x_{j}}\right)\left(1-\frac{\left|x_{j r}-x_{0 r}\right|}{x_{j r}+x_{0 r}}\right)\right]
$$

Our trade data are cross-sectional and are taken from the Direction of Trade Statistics $^{5}$ data set of the IMF. For purpose of the paper, we use 1994 trade data for the Mexican crisis and 1996 trade data for the Asian crisis.

\section{Macro control}

A number of macro-economic and financial variables are relevant in explaining the contagious nature of a crisis. Countries with macro-economic and financial imbalances are more likely to be subjected to speculative attacks. To control such factors, we employ a set of variables that have been identified as be pertinent in explaining currency crises in the empirical literature. ${ }^{6}$ These variables include, lending boom, real exchange rate appreciation, current account balance as a percentage of GDP, the government budget as a percentage of GDP, and the level of M2 over international reserve. ${ }^{7}$ We are interested in determining whether trade variables can help to explain contagion when we control for the effect of the above macroeconomic factors.

The data refer to two cross-sections of 25 emerging market countries Argentina, Brazil, Chile, China, Colombia, Czech Republic, Hungary, India, Indonesia, Jordan, Korea, Malaysia, Mexico, Pakistan, Peru, Poland, The Philippines, Sri Lanka, Thailand, South Africa, Turkey, Singapore, Taiwan,

\footnotetext{
${ }^{5}$ Taiwanese Trade data from Monthly Statistics for Exports and Imports, Taiwan Area, Department of Statistics, Ministry of Finance, Taiwan

${ }^{6}$ See Kaminsky, Lizondo and Reinhart (1998), which gives a survey of 28 empirical papers.

${ }^{7}$ Lending Boom, percentage change in real exchange rates, and M2 over international reserves have been emphasized in recent literature. See Sachs, Tornell and Velasco (1996), Tornell (1999), Grier and Grier (2001), and Corsetti, Passenti and Roubini (1998). Government budget as a percentage of GDP has also been used by Dornbusch, Goldfajn and Valdes (1995), Eichengreen, Rose and Wyplosz (1995), Frankel and Rose (1996), Eichengreen, Rose and Wyplosz (1996), and Glick and Rose (1999). Current Account as a percentage of GDP is used in Sach, Tornrell and Velasco (1996), Glick and Rose (1999), Corsetti, Pasenti and Roubini (1998), Frankel and Rose (1996), Radelet and Sachs (1998), Eichengreen, Rose and Wyplosz (1996), Kaminsky, Lizondo and Reinhart (1998), Tornell (1999), and Grier and Grier (1999).
} 
Venezuela and Zimbabwe. ${ }^{8}$ We use 1994 macro and stock data for the Mexican crisis and 1996 data for the Asian crisis. ${ }^{9}$ Stock price data have been collected from Bloomberg port, DataStream, Global Financial Data (GFD), and University of Illinois, which was largely dictated by their availability. Figure 3 and Figure 4 show the stock prices for the sampled countries for Asian and Mexican crisis respectively.

Figure 3. 1996 Stock prices
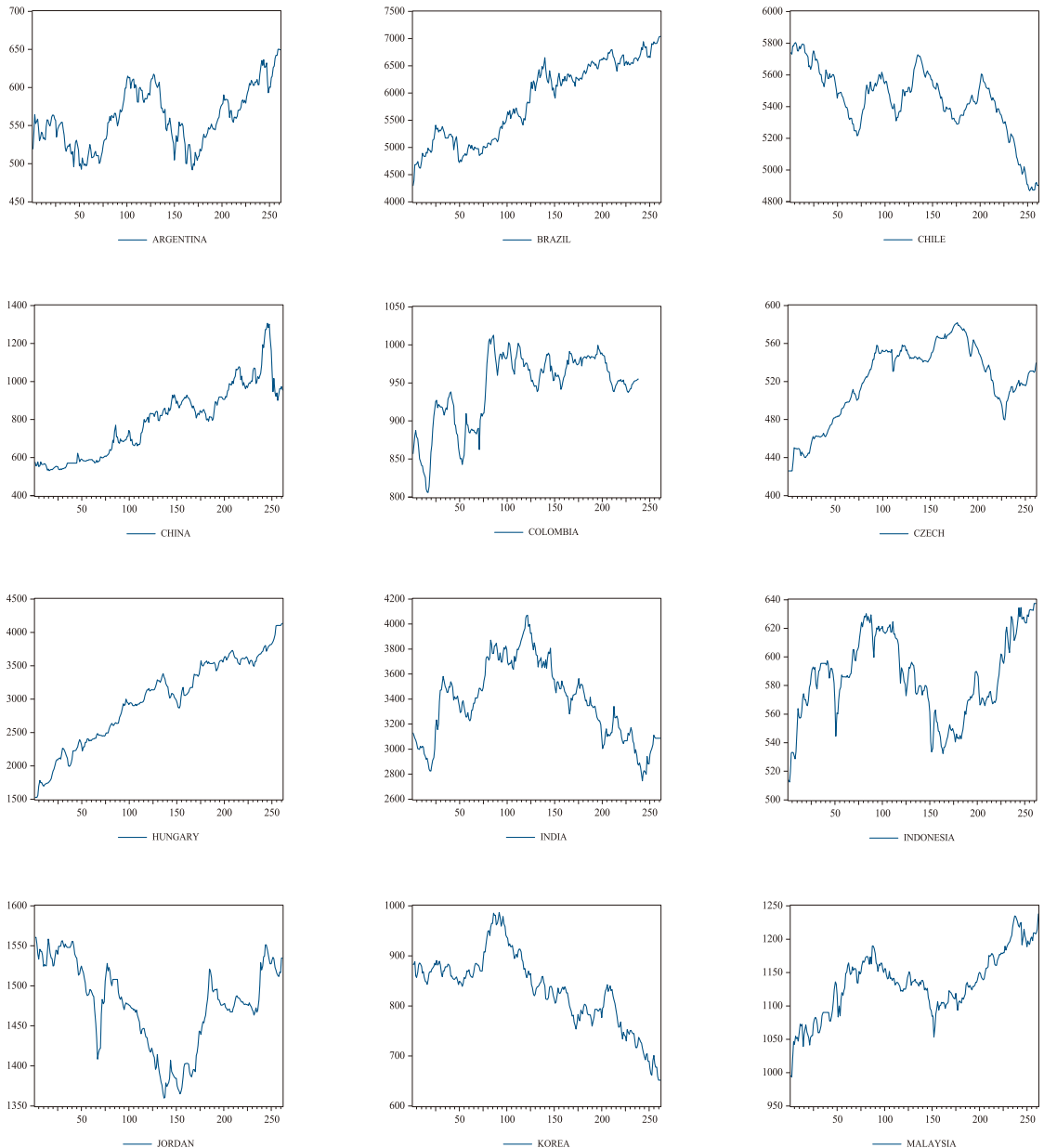

${ }^{8}$ Lack of data on of Macro and Financial Control Variables for many emerging market countries limits our sample size.

${ }^{9}$ See Appendix A for detailed discussion of our data set. 


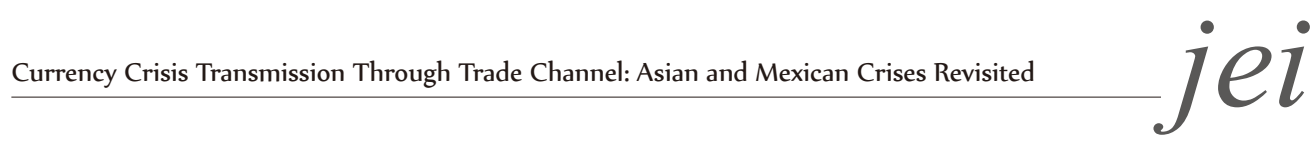

(continued)
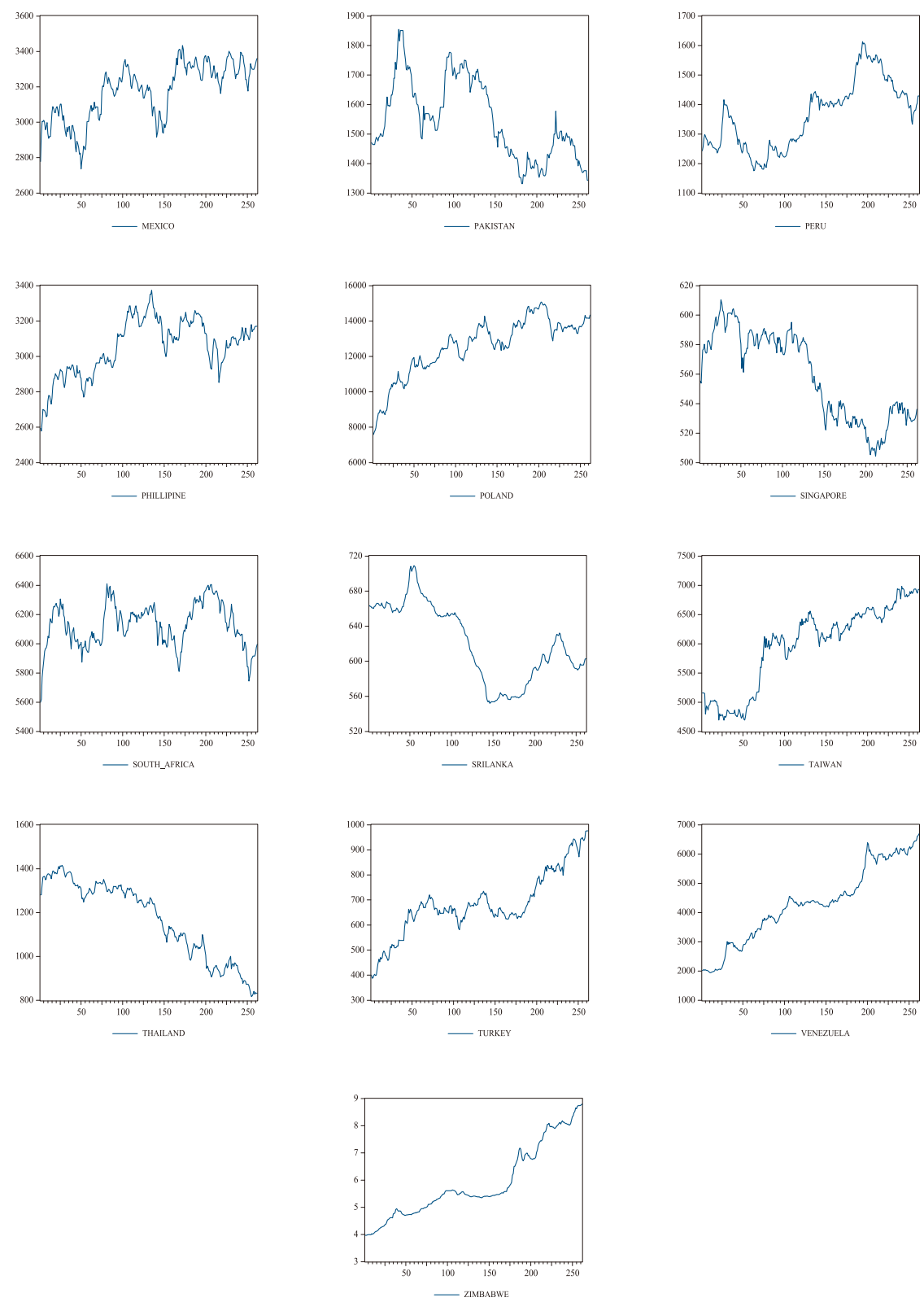
Figure 4. 1994 Stock prices
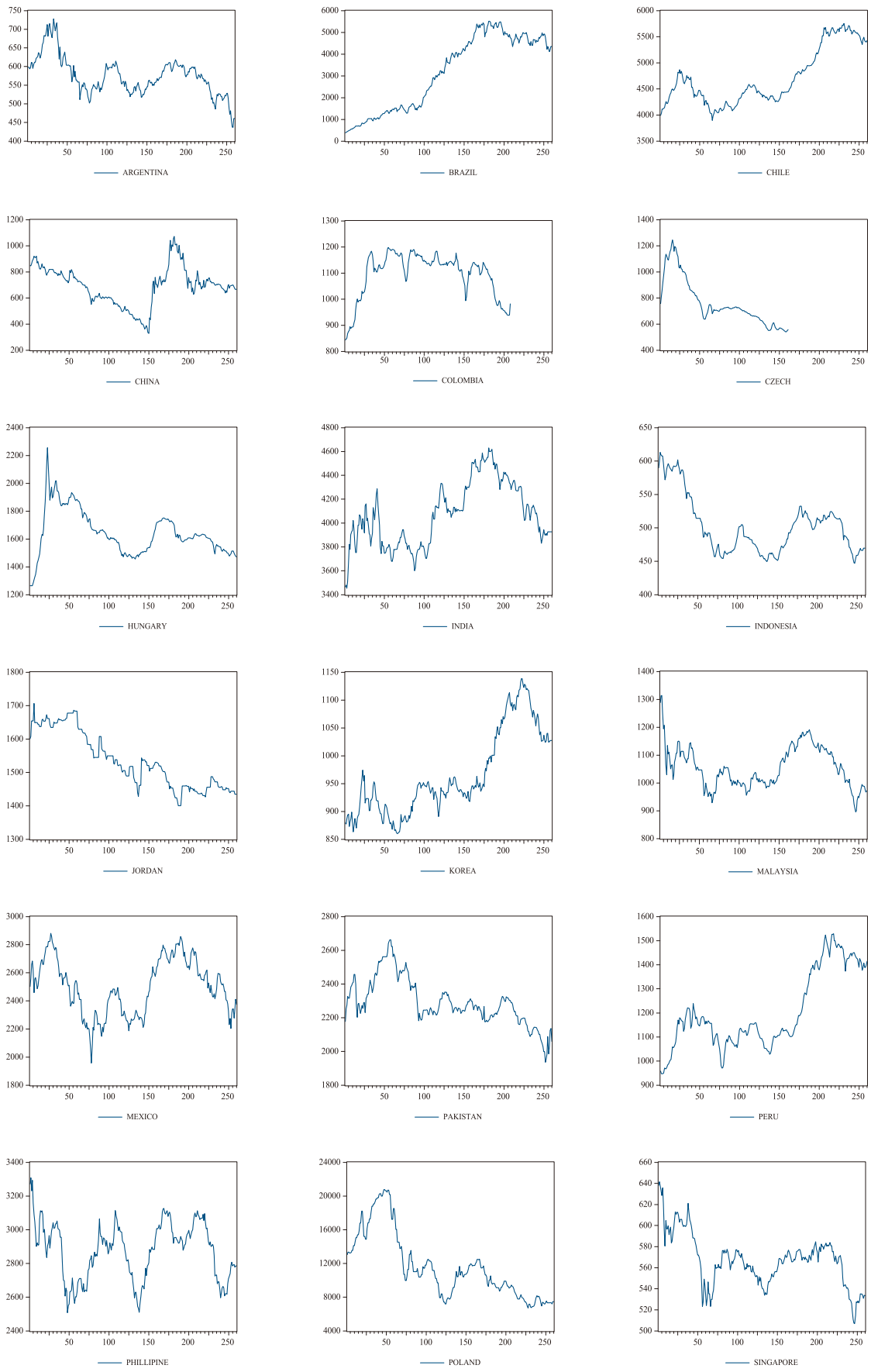
(continued)
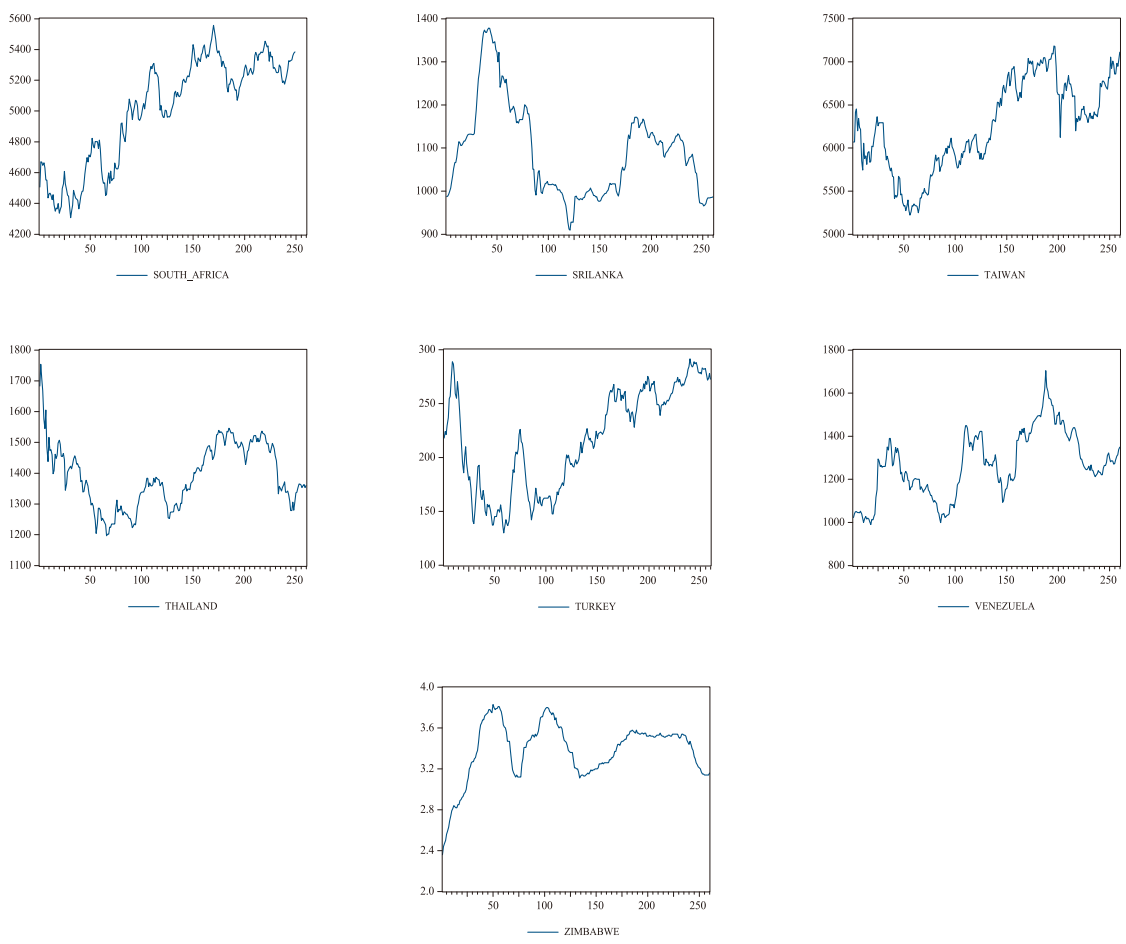

\section{Results}

The estimated results from the three regimes are presented in Tables 1 and 2. Table 1 reports all the results obtained by regressing the crisis index on the macro control variables; and the TMEC variable for the Asian crisis 1997 1998, the Mexican crisis 1993 1994, and the pooled regression of the two crises. Table 2 repeats the same estimated results but incorporating the stock market index as an additional explanatory variable. 
Table 1. Coefficients and absolute $t$-statistics of multivariate OLS

(six months horizon)

\begin{tabular}{|l|c|c|c|}
\hline \multirow{2}{*}{ Variable } & \multicolumn{3}{|c|}{ Dependent variable: Crisis index } \\
\cline { 2 - 4 } & $\begin{array}{c}\text { Asian crisis } \\
1997 \sim 1998\end{array}$ & $\begin{array}{c}\text { Mexican crisis } \\
1993 \sim 1994 .\end{array}$ & Pooled regression \\
\hline Constant & $-5.701(1.466)$ & $-8.005(2.124)^{* *}$ & $-7.233(3.495)^{* *}$ \\
\hline Lending Boom & $.002(.111)$ & $-.005(.428)$ & $-.004(.415)$ \\
\hline Real Appreciation & $.418(1.712)$ & $-.290(1.124)$ & $.034(.169)$ \\
\hline Current Account & $-.504(1.873)^{*}$ & $-.37(1.435)$ & $-.390(2.248)^{* *}$ \\
\hline M2/Reserve & $-.081(1.15)$ & $.165(1.329)$ & $-.0278(.498)$ \\
\hline Budget & $.096(.204)$ & $.084(.295)$ & $.012(.049)$ \\
\hline TMEC & $.208(2.401)^{* *}$ & $.151(1.988)^{*}$ & $.210(4.265)^{* *}$ \\
\hline$R^{2}$ & .301 & .305 & .372 \\
\hline
\end{tabular}

(Notes) (i) Heteroskedasticity consistent $t$-statistics are reported in parentheses.

(ii) * Indicates statistical significance at the $10 \%$ level

(iii) ** Indicates statistical significance at the 5\% level.

Table 2. Coefficients and absolute $t$-statistics of multivariate OLS

(six months horizon)

\begin{tabular}{|l|c|c|c|}
\hline \multirow{2}{*}{ Variable } & \multicolumn{3}{|c|}{ Dependent variable: Crisis index } \\
\cline { 2 - 4 } & $\begin{array}{c}\text { Asian crisis } \\
1997-1998\end{array}$ & $\begin{array}{c}\text { Mexican crisis } \\
1993-1994 .\end{array}$ & Pooled regression \\
\hline Constant & $-7.75(1.22)$ & $-7.27(2.09)^{* *}$ & $-8.0297(3.871)^{* *}$ \\
\hline Lending Boom & $-.005(.181)$ & $-.005(.487)$ & $-.001(.100)$ \\
\hline Real Appreciation & $-.393(1.76)^{*}$ & $-.197(.840)$ & $.053(.296)$ \\
\hline Current Account & $-.678(2.08) * *$ & $-.478(2.02)^{*}$ & $-.580(3.26)^{* *}$ \\
\hline M2/Reserve & $-.048(.771)$ & $.179(1.63)$ & $-.016(.365)$ \\
\hline Budget & $.285(.681)$ & $.296(1.22)$ & $.259(1.28)$ \\
\hline TMEC & $.219(2.12)^{* *}$ & $.115(1.79)^{*}$ & $.201(3.99)^{* *}$ \\
\hline Stock & $.119(.593)$ & $.148(3.30)^{* *}$ & $.153(2.63)^{* *}$ \\
\hline$R^{2}$ & .314 & .477 & .432 \\
\hline
\end{tabular}

(Notes) (i) Heteroskedasticity consistent $t$-statistics are reported in parentheses.

(ii) * Indicates statistical significance at the $10 \%$ level

(iii) $* *$ Indicates statistical significance at the 5\% level. 
The variable TMEC has the expected positive sign and is significant at the $5 \%$ level for the Asian crisis. Countries that have strong trade links ${ }^{10}$ with the first victim11 through export competition in a third market have depreciated their currency or lost reserves in the Asian crisis. Except for the current account, which is significant at the $10 \%$ level and also has the expected negative sign, none of the macro control variables are significant. The result suggests that the current account deficits tend to escalate the severity of crisis. For the Asian crisis, strong export competition between first victim and other countries in the third market also explain severity of crisis. For the Mexican crisis, it is evident that TMEC is significant, albeit at the $10 \%$ level, and positively related to the crisis index for Mexican peso. Variations in economic fundamentals, including current account, do not appear to explain the spread of crisis. The only variable which acts as a conduit of the Mexican currency crisis spillover appears to be the trade channel. For the pooled regression, we stacked 48 observations for the Asian and Mexican currency crises, and estimated the model represented by Equation 3. As for the estimates obtained from the pooled model, once again, we find that both TMEC and the current account have the expected signs and are also statistically significant.

The results presented in Table 2 indicate that the equities market cannot explain the severity of the Asian currency crisis, but did play a role in explaining the severity of the Mexican currency crisis. As we incorporate stock market in our model, the coefficient of current account turns out insignificant in each of the two crises. The addition of the stock market index in the model does not change the results for the pooled regression. This indicates that stock markets play as a factor in explaining spillover effect of currency crisis in common sample, which is also an interesting finding of our paper.

The research question is, whether the model that explains contagion in the Asian crisis can also explain the severity of the crisis spread in the Mexican case. We are interested in knowing whether the coefficients of the pooled regression in Table 2 are stable. Put differently, we examine whether or not the coefficients are not different in the two periods. This is done by performing the Chow test on the models involving TMEC. Since F [8, 32]: $0.659<F C{ }_{0.05}=2.27$, we cannot reject the null hypothesis that the model

\footnotetext{
${ }^{10}$ Through bilateral trading or export competition in the third market.

${ }^{11}$ The first victims were, Thailand in the Asian crisis, 1997-98, and Mexico in the Latin Crisis, 1994 1995
} 
that explains the Asian crisis can also explain the Mexican peso crisis. Statistically, the coefficients of the model presented under pooled regression are no different in the two periods.

Because the paper employs pooled regression method, we need to ask if country effects are present. We assess this under three different models: (a) the simple OLS model; (b) a fixed effect model; and (c) a random effect model. An F statistic is applied to test the null hypothesis of no country specific effects against the alternative that there are country specific fixed effects.

Since $F_{\cdot 05}, 23,17=2.19$, we cannot reject the null hypothesis of no fixed effects. A Breusch Pagan specification procedure is employed to test the null hypothesis of no country effects against the alternative of random effects. The Lagrange Multiplier (LM) test statistic is 0.636. Under the null, the LM follows a chi-squared distribution with 1 degree of freedom. Since LM statistic is lower than the $1 \%$ critical value, we cannot reject the null hypothesis of no random effects. Thus, we determine simple OLS as our correct specification.

We test the robustness of our benchmark cases by taking different sets of macro control variables. We also test the sensitivity of our result by using different measures of the dependent variable and variant measures of trade variable. We find that the estimated coefficients of TMEC in the pooled regressions are very robust to these tests. In addition, we also conducted several sensitivity tests such as, by excluding outliers; and also by changing the country composition of the sample. The findings are still relatively robust.

\section{Conclusion}

Our results show that trade links through export competition in a third market with the ground zero country is statistically significant suggesting that this link tends to make the balance of payments crises more severe. As is evident, this is true for both the Asian and Mexican currency crises. These results are also robust to different specifications. Trade links by and large, capture the regional trade pattern and are important and useful in explaining the severity of the crises in both episodes.

We incorporated the variation in equity markets as another potential conduit 
for contagion. However, the results indicate that stock market as source of currency crisis spillover is all but ruled out in the Asian currency crisis. Even though, we did not find a direct link between stock market variability and crises episodes in our study, the role of deteriorating stock prices in the devaluation of Thai Bath cannot be completely ignored. Once the bath was depreciated it just put further competitive pressure on Thailand's neighbors who compete for export in the common third markets. This also forced them to devaluate their currencies.

This study has limitation. This macro-level study uses trade data that is not disaggregated by industry. Therefore, it may not accurately measure competition in a third market. In spite of this limitation, we believe that this paper provides some useful insight into the issue of the propagation of currency crises. For future research, it will be interesting to conduct a similar study on contagion through trade channels with sector-specific trade data. This will also shed light on how the dynamics of trade unfolds in the bilateral and regional context. Sector-specific export competition in a third market will provide a better measure of competition. This would make the tale of competitive devaluation clearer and more comprehensible.

Contagious currency crises are regional and they spread through the trade channel. Policies aim at diversifying the trade base could limit the propagation of a crisis. Countries could also fix their exchange rates with major trade partners collectively. This policy may help them to avoid speculative attacks following loss of international competitiveness. However, it may lead to destabilizing speculative attacks on currencies if the collective agreement is not firm and credible. Countries may adopt a regional currency such as Euro, to avoid severity of currency crises among members through competitive devaluation.

Received 21 September 2018, 2 November 2018, Accepted 8 November 2018 


\section{References}

Calvo, G. and E. Mendoza. "Rational Contagion and the Globalization of Securities Markets." Journal of International Economics 51(1) (2000): 79-113.

Corsetti, G., P. Passenti, and N. Roubini. "Paper Tigers? A Model of the Asian Crisis." Working Paper No. 6783, National Bureau of Economic Research ,1998

Corsetti, Giancarlo, Paolo Pesenti, Nouriel Roubini, and Cédric Tille. "Trade and Contagions Devaluations: A Welfare-based Approach." Journal of International Economics 51(2000) : 217-241.

Dornbush, R., I. Goldfajn, and R. Valdes. "Currency Crises and Collapses." Brookings Paper on Economic Activity 0(1) (1995): 219-70.

Drazen, A. "Political Contagion in Currency Crises." National Bureau of Economic Research Working Paper No. 7211, 1999

Eichengreen, B., A. Rose, and C. Wyplosz. "Exchange Market Mayhem: The Antecedents and Aftermath of Speculative Attacks." Economic Policy 21 (1995): 249-96.

Eichengreen, B., A. Rose, and C. Wyplosz. 1996. "Contagious Currency Crises." Working Paper No. 5681, National Bureau of Economic Research, 1996.

Forbes, Kristin "The Asian Flu and Russian Virus: Firm-Level Evidence on How Crises are Transmitted Internationally.” NBER Working Paper No. 7807, 2000

Frankel, J. and A. K. Rose. "Currency Crashes in Emerging Markets: An Empirical Treatment." Journal of International Economics 41(3) (1996): 35166. 
Frankel, J. and S. Schmukler. "Country Funds and Asymmetric Information." International Journal of Finance and Economics 5(3) (2000) 177-95.

Gerlach, Stefan and Frank Smets. "Contagious Speculative Attacks." European Journal of Political Economy 11(1) (1995): 45-63.

Glick, R. and A. K. Rose. "Contagion and Trade: Why are Currency Crises Regional." Journal of International Money and Finance 18(4) (1999): 603-17.

Grier, K. and R. Grier. "Exchange Rate Regimes and the Cross-Country Distribution of the 1997 Financial Crisis" Economic Inquiry 39(1) (2001): 13948.

Granger, C.W.J, Huang, B., Yang, C.W. “A Bivariate Causality between Stock Prices and Exchange Rates: Evidence form Recent Asian Flu." The Quarterly Review of Economics and Finance 40 (2000): 337-354.

Haidar J. I. "Currency Crisis Transmission through International trade." Economic Modelling 29 (2012): 151-157.

Haile, F. Pozo, S. "Currency Crisis Contagion and the Identification of Transmission Channels." International Review of Economics and Finance 17(2008): 572-588.

Huh, Chan and Kenneth Kasa "A Dynamic Model of Export Competition, Policy Coordination and Simultaneous Currency Collapse," Working Paper No. PB97-08, Federal Reserve Bank of San Francisco Center for Pacific Basin Studies, 1997

Ito, T., and Y. Hashimoto. "High-Frequency Contagion of Currency Crises in Asia," Asian Economic Journal vol. 19, n4 (2005) :357-81.

Ito, Takatoshi and Yuko Hashimoto. "High-Frequency Contagion of Currency Crises in Asia.” NBER Working Paper, No.9376, 2002. 
Kaminsky, G. and C. Reinhart. "The Twin Crises: The Causes of Banking and Balance of Payments Problem," American Economic Review 89(3) (1999): 473500 .

Kaminsky, G. and C. Reinhart. 2000. "On Crises, Contagion, and Confusion, Journal of International Economics 51(1) (2000): 145-68.

Kaminsky, G. and S. L. Schmukler. "What Triggers Market Jitters? A Chronicle of the

Asian Crisis," International Finance Discussion Paper No. 634, Board of Governors of the Federal Reserve System, 1999.

Kaminsky, G. and S. Lizondo, and C. M. Reinhart. "Leading Indicators of Currency Crises," Staff Papers, International Monetary Fund, 45,1998.

Khan, Saleheen, Islam Faridul, and Ahmed Syed. "The Asian Crisis: An Economic Analysis of the Causes," Journal of Developing Areas Vol. 39, 1 (2005): 169-90.

Khalid, Ahmed M., and Masahiro Kawai. "Was financial market contagion the source of economic crisis in Asia?: Evidence using a multivariate VAR model." Journal of Asian Economics Vol. 14, No. 1 (2003): 131-156.

Krugman P. “Currency Crises,” MIT, mimeo, 1998.

Masson, P. "Contagion Effect: Monsoonal Effects, Spillovers, and Jump Between Multiple Equilibria," Working Paper No. 142, International Monetary Fund, 1998.

Radelet, S. and J. Sachs. "The Onset of East Asian Financial Crisis," Working Paper No. 6680, National Bereau of Economic Research, 1998.

Rigobon, R. "Informational Speculative Attacks: Good News is No News," 
MIT, Mimeo, 1998.

Sachs, J., A. Tornell, and A. Velasco. "Financial Crises in Emerging Markets: The Lessons from 1995." Brookings Paper on Economic Activity 10(1) (1996): $147-98$.

Tornell, A. 1999. "Common Fundamentals in the Tequila and Asian Crises," Working Paper No. 7139, National Bureau of Economic Research ,1999.

Van Rijckehem, C. and B. Weder. 1999. "Sources of Contagion: Finance or Trade,” Working Paper No. 146, International Monetary Fund, 1998 


\section{Appendix A: Summary statistics}

Table A1. Mexican peso crisis $1994 \sim 1995$

\begin{tabular}{|l|c|c|}
\hline \multicolumn{1}{|c|}{ Variable } & Mean & Standard Deviation \\
\hline Lending Boom & 18.262 & 60.401 \\
\hline Real Appreciation & -1.577 & 5.765 \\
\hline Current Account & -1.824 & 5.169 \\
\hline Budget & -1.756 & 4.842 \\
\hline M2/ Reserve & 5.784 & 7.602 \\
\hline Crisis Index & -1.629 & 5.979 \\
\hline TMEC & 29.80 & 15.59 \\
\hline \% 1 Stock & 4.003 & 18.688 \\
\hline
\end{tabular}

Table A2. Asian crisis $1997 \sim 1998$

\begin{tabular}{|l|c|c|}
\hline \multicolumn{1}{|c|}{ Variable } & Mean & Standard Deviation \\
\hline Lending Boom & 11.289 & 66.836 \\
\hline Real Appreciation & .176 & 5.04 \\
\hline Current Account & -1.869 & 5.591 \\
\hline Budget & -1.279 & 4.816 \\
\hline M2/ Reserve & 8.874 & 17.539 \\
\hline Crisis Index & 6.702 & 9.76 \\
\hline TMEC & 58.614 & 24.224 \\
\hline \% & 8.279 & 13.264 \\
\hline
\end{tabular}




\section{Appendix B: Data}

This Appendix describes the construction of the data. Most of the data come from IMF's International Financial Statistics. Taiwanese data are from the Financial Statistics (IMF) of Central Bank of China (www.cbc.gov.tw) and from various issues of Monthly Bulletin of Statistics of the Republic of China.

\section{- Real Exchange Rate Appreciation:}

As in Glick and Rose (1999), the real exchange rate appreciation was calculated as the percentage change in the real exchange rate between the average of the three previous years and the crisis year. Most of the real exchange rate data are from J.P. Morgan \& Co. The data for Jordan, Hungary, Checzh Republic, Sri Lanka, Zimbabwe, Poland, and China were not available from J.P. Morgan \& Co. We calculated the real exchange rates for these countries as the weighted sum of the bilateral real exchange rates (using CPI's) with respect to the Dollar, Yen, and DM. Average nominal exchange rates and CPI data for this purpose were obtained from IMF's International Financial Statistics.

\section{- Lending Boom:}

First, we got the ratio of the claims on the private sector of the deposit money banks (IFS line 32d) to nominal GDP (IFS line 99b). We then used the growth rate of this ratio between 1990 and 1994 for the Mexican crisis and 1992 and 1996 for the Asian crisis.

\section{- Current Account:}

The current account (IFS line 78al) has been converted to national currency using the annual average exchange rate (IFS line rf). We used the converted current account in 1996 as a percentage of 1996 GDP for the Asian crisis and the ratio of current account in 94 to GDP of 1994 for the Latin crisis. A positive sign on this variable denotes current account surplus, while a negative sign denotes a current account deficit. 


\section{- Budget:}

The variable Budget is constructed as government budget (IFS line 80) as a percentage of nominal GDP. A budget surplus shows a positive sign, and deficit shows a negative sign. We then used the ratio of 1996 for the Asian crisis and 1994 for the Mexican crisis.

\section{$\cdot$ - M2 / Reserves:}

We converted total reserves minus gold (IFS line 11) to national currency, using average exchange rate. We calculated M2 as the sum of money (IFS line 34) and quasi money (IFS line 35). The ratio of M2 to total reserve (minus gold) of 1996 was used as a reserve adequacy for the Asian crisis and the ratio of 1994 was used for the Mexican peso crisis.

\section{- Credit Growth:}

We used the annual growth rate of domestic credit (IFS line 32) between the years of 1995 and 1996 for the Asian crisis and 1993 and 1994 for the tequila crisis.

$. \% \Delta M 1:$

We used the log difference of M1 between the years of 1993 and 1994 for the Mexican crisis and 1995 and 1996 for the Asian crisis.

\section{- Capital Inflow:}

We constructed this series by summing the capital account (IFS line 78bc), the financial account (IFS line 78bj), and net errors and omissions (IFS 78ca). The sum was converted to national currency by multiplying it with annual average exchange rate; then we obtained a ratio of that converted sum to nominal GDP. The ratio in 1996 was used for Asian crisis and the ratio in 1994 for the peso crisis. 